\title{
ANALISIS KETERSEDIAAN PANGAN KOTA MALANG
}

\section{ANALYSIS OF FOOD AVAILABILITY IN MALANG}

\author{
Dita Atasa $^{* 1}$, Tri Wahyu Nugroho \\ ${ }^{1}$ Jurusan Agribisnis, Fakultas Pertanian, Universitas Pembangunan Nasional "Veteran" Jawa Timur \\ Jl. Rungkut Madya, Gn. Anyar, Surabaya 60294 Jawa Timur, Indonesia \\ ${ }^{2}$ Jurusan Sosial Ekonomi Pertanian, Fakultas Pertanian, Universitas Brawijaya \\ Jl. Veteran, Malang 65145 Jawa Timur, Indonesia \\ ${ }^{*}$ E-mail: dita.atasa.agribis@upnjatim.ac.id \\ (Diterima 05-04-2021; Disetujui 03-06-2021)
}

\begin{abstract}
ABSTRAK
Penelitian ini bertujuan untuk menganalisis ketersediaan pangan, dan keadaan keragaman pangan di Kota Malang, serta menganalisis formulasi sasaran, kebutuhan penyediaan, dan produksi pangan di Kota Malang tahun 2016-2019. Analisis yang digunakan adalah Neraca Bahan Makanan (NBM) dan Pola Pangan Harapan (PPH). Hasil dari penelitian ini menunjukkan bahwa ketersediaan pangan di Kota Malang didominasi oleh sumber pangan nabati dengan persentase sebesar $81,75 \%$. Nilai ketersediaan energi sebesar $2.227 \mathrm{kkal} / \mathrm{kap} / \mathrm{hari}$ dan protein sebesar 63,77 gram $/ \mathrm{kap} /$ hari. Kualitas ketersediaan pangan yang diukur dari capaian skor PPH, dengan skor sebesar 89,33 yang menunjukkan bahwa keberagaman ketersediaan belum maksimal. Ketersediaan energi Kota Malang belum memenuhi standar rekomendasi Angka Kecukupan Energi (AKE) dan ketersediaan protein melebihi Angka Kecukupan Protein (AKP) yang dikeluarkan oleh Widyakarya Nasional Pangan dan Gizi (WNPG) X Tahun 2012, dimana AKE dan AKP ideal sebesar $2.400 \mathrm{kkal} / \mathrm{kap} / \mathrm{hari}$ dan protein sebesar 63 gram/kap/hari. Angka Kecukupan Energi (AKE) dan Angka Kecukupan Protein (AKP) skor PPH, dengan skor sebesar 89,33 yang menunjukkan bahwa keberagaman ketersediaan belum maksimal. Ketersediaan energi Kota Malang belum memenuhi standar rekomendasi Angka Kecukupan Energi (AKE) dan ketersediaan protein melebihi Angka Kecukupan Protein (AKP) yang dikeluarkan oleh Widyakarya Nasional Pangan dan Gizi (WNPG) X Tahun 2012, dimana AKE dan AKP ideal sebesar $2.400 \mathrm{kkal} / \mathrm{kap} / \mathrm{hari}$ dan protein sebesar 63 gram/kap/hari. Angka Kecukupan Energi (AKE) dan Angka Kecukupan Protein (AKP) ketersediaan pangan ideal dapat dicapai dengan peningkatan ketersediaan meliputi; padi-padian, dan buah biji berminyak, sayuran dan buah dan penurunan umbi-umbian, kacang-kacangan, minyak dan lemak, pangan hewani, dan gula.
\end{abstract}

Kata Kunci: Ketersediaan Pangan, Neraca Bahan Makanan (NBM), Pola Pangan Harapan (PPH)

\section{ABSTRACT}

The research purposes are analyzing food availability, food procurement diversity, and analyzing target formulation, procurement necessity, and food production in Malang in 2016 - 2019. The analysis used is Food Balance Sheet (FBS) and Food Desirable Dietary Pattern (FDDP). The analysis result shows that the food availability in Malang is dominated by plant food source with $81,75 \%$ of percentages. The total of energy availability value is $2.227 \mathrm{kcal} / \mathrm{kap} /$ day and protein 63,77 gram/kap/day. The quality of food availability measured with FDDP is 89,33 which shows that food diversity is not maximal yet. Overall, the food availability energy in Malang has not fulfilled Recommended Dietary Energy (RDE) standard and the protein is more than Recommended Dietary Protein (RDP), in which RDE ideal is $2.400 \mathrm{kcal} / \mathrm{kap} /$ day and RDP is 63 gram/kap/day. RDE and RDP of ideal food availability can be reached by increasing and decreasing food commodity group gradually from 2016 to 2019. The food commodity groups that need to be increased are such as; cereals, pulse nut and oil seeds, animal food, vegetable, and 
fruit. While the commodity groups that need to be decreased are such as starchy food, nut, oil and fat, animal food, and sugar.

Keywords: Food Availability, Food Balance Sheet (FBS), Food Desirable Dietary Pattern

\section{PENDAHULUAN}

Pangan merupakan salah satu kebutuhan dasar manusia sehingga pemenuhannya menjadi salah satu hak asasi setiap rakyat Indonesia yang harus dipenuhi secara bersama-sama oleh negara dan masyarakatnya sebagaimana dinyatakan dalam UU No. 18 Tahun 2012 tentang pangan. Terjaminnya hak atas pangan di Indonesia dapat mencegah dan mengurangi target jumlah penduduk miskin dan kurang gizi pada anak-anak. Target tersebut sesuai dengan komitmen pada konferensi PBB mengenai Suistainable Development Goals (SDGs) yang tercakup dalam Goal 2, yaitu "End hunger, achieve food security and improved nutrition, and promote suistanable agriculture” yang akan dicapai pada tahun 2030 .

Akses pangan setiap individu harus dijamin agar dapat memenuhi kebutuhan pangan bagi masyarakat, rumah tangga, dan perseorangan secara berkelanjutan dan tidak kekurangan gizi. Akses pangan setiap individu ini sangat tergantung pada ketersediaan pangan dan kemampuan untuk mengaksesnya secara terusmenerus (continue). Dalam memenuhi kebutuhan pangan masyarakat dan meningkatkan kuantitas serta kualitas konsumsi pangan, diperlukan target pencapaian angka ketersediaan pangan per kapita per tahun sesuai dengan angka kecukupan gizinya.

Menurut Kantor Ketahanan Pangan (2015), ketahanan pangan tahun 2015 di Kota Malang menunjukkan kondisi yang cukup baik. Mayoritas kelurahan di Kota Malang termasuk dalam kategori tahan pangan, yaitu sebanyak 51 kelurahan atau 94,76\%. Selain itu, untuk tahun 2015 kelurahan yang masuk dalam kategori sangat tahan ada 6 kelurahan atau sebesar 10,53\%. Akan tetapi, apabila dilihat berdasarkan indikator kerawanan pangan, indikator yang paling kronis tergolong rawan pangan adalah indikator konsumsi normatif. Hal ini dikarenakan daerah kota seperti Kota Malang tidak banyak memiliki lahan pertanian. Pembangunan di Kota Malang tidak difokuskan kepada bidang pertanian namun lebih ke bidang non pertanian, sehingga mengakibatkan hasil produksi pertanian yang diperoleh sedikit. Secara tidak langsung menyebabkan konsumsi normatif di Kota Malang menjadi sangat rendah. 
Informasi mengenai penyediaan pangan dapat dilakukan dengan penyediaan data NBM dan Pola Pangan Harapan (PPH) di masing-masing daerah. Hasil dari penyusunan NBM dan PPH digunakan sebagai bahan pertimbangan dalam perencanaan pangan dan gizi di tingkat wilayah. Tabel NBM merupakan tabel yang memberikan gambaran tentang situasi ketersediaan pangan untuk dikonsumsi penduduk suatu wilayah dalam kurun waktu. Sementara itu, metode PPH digunakan untuk menilai tingkat keragaman ketersediaan pangan pada suatu waktu yaitu metode $\mathrm{PPH}$ dengan skor 100 sebagai PPH ideal. Skor PPH merupakan cermin situasi kualitas pangan di suatu wilayah. Selain itu, digunakan juga perhitungan mutu pangan melalui PPH dari segi konsumsinya.

Penelitian ini difokuskan untuk menganalisis ketersediaan pangan di Kota Malang dengan pendekatan NBM dan PPH. Berkenaan dengan hal tersebut penelitian ini memberikan informasi kondisi ketersediaan pangan baik dari segi kuantitas melalui NBM dan dari segi kualitas (keragaman) melalui pendekatan PPH selanjutnya manganalisis formulasi sasaran kebutuhan penyediaan dan produksi di Kota Malang tahun 20162019 yang dapat dijadikan bahan acuan dalam pengambilan kebijakan yang berkaitan dengan ketahanan pangan Kota Malang.

\section{METODE PENELITIAN}

Penelitian ini dilakukan pada bulan Februari-Maret 2017. Jenis data yang digunakan dalam penelitian ini adalah data primer dan data sekunder. Data primer yaitu data impor (mendatangkan sejumlah bahan pangan dari daerah/kota lain) berasal dari survei pasar tradisional. Data sekunder yang diperoleh dari instansi terkait dengan program ketahanan pangan, khususnya data untuk mengetahui ketersediaan pangan di Kota Malang. Data tersebut meliputi data produksi pangan, data impor bahan makanan tahun, data jumlah penduduk, dan data laju pertumbuhan penduduk. Data-data tersebut diperoleh dari Badan Pusat Statistik (BPS) Kota Malang, Dinas Pertanian dan Ketahanan Pangan Kota Malang, dan Dinas Perdagangan Kota Malang.

Penentuan sampel untuk memperoleh data survei pasar menggunakan metode pengambilan sampel acak distratifikasi (stratified random sampling). Hasil pengambilan sampel secara acak, dapat disimpulkan 3 sampel sub populasi Pasar Kelas 1 yang 
terdiri atas Pasar Blimbing, Tawangmangu, dan Oro-oro Dowo, Pasar Kelas 2 yaitu Pasar Mergan, sedangkan Pasar Kelas 3 yaitu Pasar Lesanpuro. Jumlah responden yang dijadikan sebagai sampel sebanyak 84 responden, dengan rincian; Pasar Belimbing sebanyak 24 responden, Pasar Tawangmangu sebanyak 23 responden, Pasar Oro-oro Dowo 17 responden, Pasar Mergan 7 responden, dan Pasar Lesanpuro 13 responden.

Analisis data yang digunakan adalah Neraca Bahan Makanan (NBM), Pola Pangan Harapan (PPH) dan peramalan. NBM disusun dalam suatu Tabel NBM terdiri atas 19 kolom yang terbagi menjadi 3 kelompok penyajian yaitu pengadaan atau penyediaan, penggunaan atau pemakaian dan ketersediaan per kapita. Jumlah pengadaan harus sama dengan jumlah penggunaan. Komponen pengadaan meliputi produksi (masukan dan keluaran), perubahan stok, impor dan ekspor. Sedangkan komponen penggunaan meliputi penggunaan untuk pakan, bibit, industri (makanan dan bukan makanan), tercecer, dan bahan makanan yang tersedia untuk dikonsumsi. Jenis bahan makanan yang dicakup dalam NBM adalah bahan makanan yang bersumber dari nabati maupun hewani dan lazim dikonsumsi oleh penduduk. Bahan makanan tersebut dikelompokkan menjadi 11 kelompok menurut jenisnya.

Berdasarkan NBM dapat diketahui ketersediaan per kapita yang diperoleh dari ketersediaan masing-masing bahan makanan dibagi dengan jumlah penduduk dan disajikan dalam bentuk kuantum (volume) dan kandungan gizinya dalam satuan kkal energi, gram protein. Satuan untuk mengukur tingkat ketersediaan pangan adalah volume pangan (ton/tahun, $\mathrm{kg} / \mathrm{kapita} / \mathrm{hari}$, gram/kapita/hari), energi (kal/kapita/hari) serta zat gizi protein (g/kapita/hari).

Perhitungan Pola Pangan Harapan (PPH) dalam penelitian ini menggunakan basic data dari Neraca Bahan Makanan (NBM). Komponen dalam perhitungan skor PPH adalah kelompok pangan, jumlah pangan dalam satuan gram/kapita/hari, jumlah pangan dalam satuan kkal/kapita/hari, persen energi (\%), persen AKE (\% AKE), bobot, skor aktual, skor AKE, skor maksimal dan skor PPH.

Formulasi sasaran dan kebutuhan penyediaan serta produksi pangan dilakukan untuk menghitung perkiraan ketersediaan pangan sesuai dengan keragaman pangan guna memenuhi 
kebutuhan pangan dan gizi bagi penduduk Kota Malang tahun 2016-2019. Formulasi sasaran PPH ideal berdasarkan data PPH 2016 sebagai tahun dasar, dan formulasi tercapainya PPH ideal pada tahun 2019. Selanjutnya data formulasi sasaran PPH tahun 2016-2019 digunakan untuk menyusun formulasi sasaran penyediaan pangan dalam satuan ton.

\section{HASIL DAN PEMBAHASAN}

\section{Ketersediaan Energi dan Protein Kota Malang}

Ketersediaan pangan merupakan salah satu aspek penting dalam mewujudkan ketahanan pangan suatu wilayah. Penyediaan pangan diperlukan untuk memenuhi kebutuhan akan pangan dan gizi bagi masyarakat, rumah tangga dan perseorangan secara berkelanjutan. Menurut BKP (2015), dalam memenuhi kebutuhan pangan masyarakat dan meningkatkan kuntitas serta kualitas konsumsi pangan, diperlukan target pencapaian angka ketersediaan pangan per kapita per tahun. Berdasarakan hasil Widyakarya Nasional Pangan dan Gizi (WNPG) X tahun 2012 merekomendasikan ketetapan tingkat ketersediaan pangan per kapita bagi setiap penduduk dalam suatu wilayah. Pada tingkat penyediaan energi sebesar $2.400 \mathrm{kkal} / \mathrm{kapita} / \mathrm{hari}$, sedangkan untuk protein sebesar 63 gram/kapita/hari (Asmara et all, 2016).

Tabel 1. Ketersediaan Pangan Kota Malang Tahun 2016

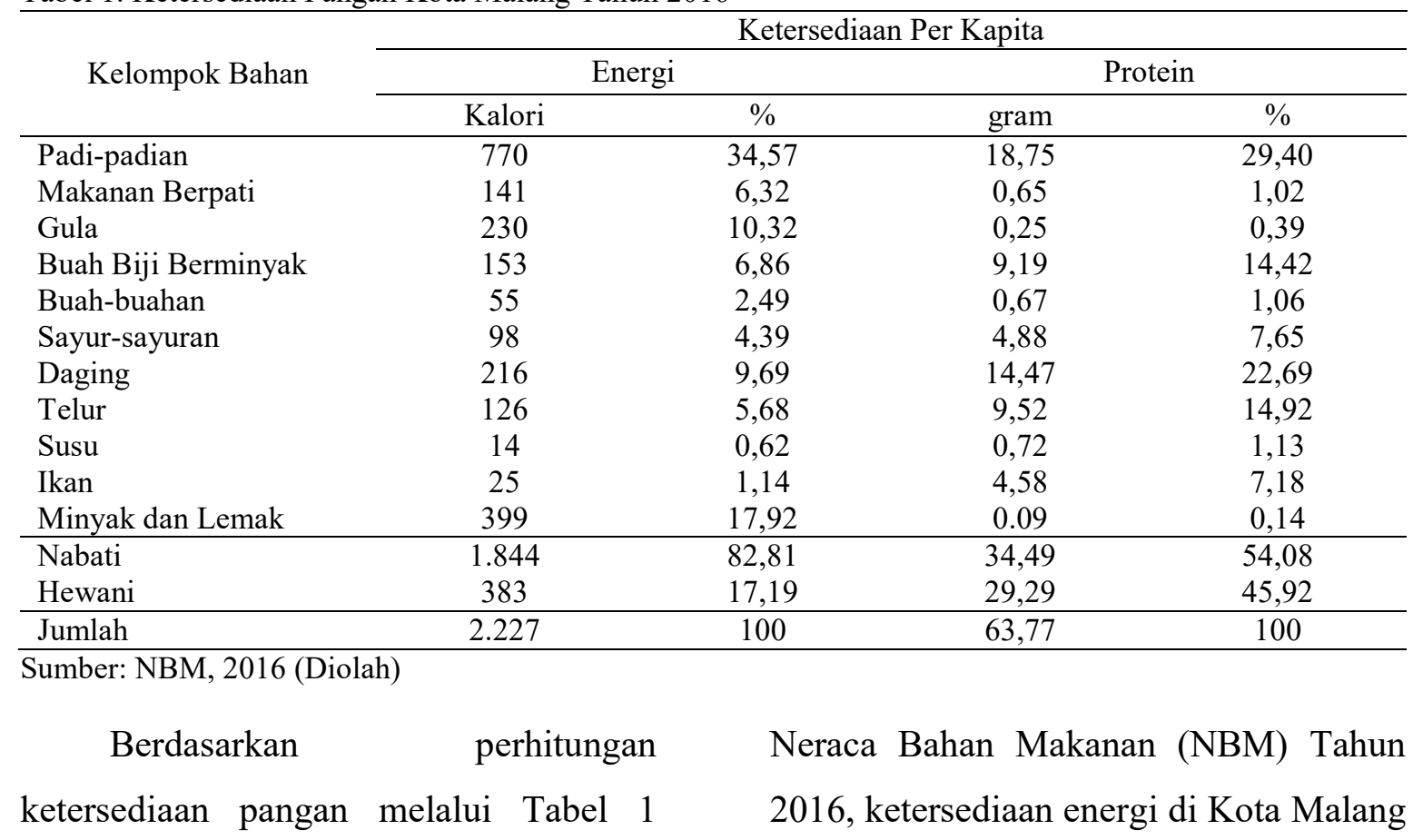


belum memenuhi standar penyediaan pangan yang direkomendasikan oleh WNPG $\mathrm{X}$, sedangkan ketersediaan protein melebihi jumlah ideal. Pada Ketersediaan energi Kota Malang mencapai $2.227 \mathrm{kkal} / \mathrm{kapita} / \mathrm{hari}$, dan protein 63,77 gram/kapita/hari. Menurut Arifin 2011 dalam Gevisioner et al (2015), ketersediaan pangan yang cukup di suatu wilayah dapat dijadikan indikator pemenuhan konsumsi pangan masyarakat. Pada wilayah dimana ketersediaan pangan yang cukup tinggi, cenderung memberikan gambaran situasi konsumsi pangan yang lebih baik.

Ketersediaan energi Kota Malang didominasi oleh sumber pangan nabati sebesar $1.844 \mathrm{kkal} / \mathrm{kapita} / \mathrm{hari}$ atau berkontribusi 82,81\%. Kelompok pangan yang berkontribusi terbesar terhadap ketersediaan energi atau kalori adalah padi-padian menyumbang sebesar 770 $\mathrm{kkal} /$ hari atau 34,57 \%, kemudian minyak dan lemak sebesar 399 kkal/kapita/hari atau $17,92 \%$, dan gula sebesar 230 $\mathrm{kkal} / \mathrm{kapita} /$ hari atau $10,32 \%$, serta daging sebesar 216 atau 10,34\%.

Sumber pangan nabati mendominasi ketersediaan protein dengan menyumbang 54,08\%. Sumber pangan hewani menyumbang sebesar 45,92\%. Kelompok pangan lainnya berkontribusi kurang dari 10\%. Padi-padian merupakan penyumbang protein terbesar dalam keseluruhan kelompok pangan dengan persentase sebesar 29,40\% atau setara dengan 18,75 gram/kapita/hari. Daging berada diurutan kedua setelah padipadian dengan menyumbang protein sebesar 14,47 gram/kapita/hari atau 22,69\%. Kelompok bahan pangan lainnya menyumbang energi kurang dari $20 \%$.

\section{Asal Penyediaan Pangan dan Penggunaan Pangan}

Asal penyediaan pangan di Kota Malang berasal dari produksi maupun impor (mendatangkan bahan pangan dari daerah atau kota lain). Sebagian besar penyediaan pangan untuk sebagian kelompok pangan berasal dari impor kota/kabupaten lain. Sebagian besar penyediaan komoditas pangan berasal dari impor.

Kota Malang adalah daerah perkotaan dan terbatasnya lahan untuk pertanian. Impor (mendatangkan beberapa komoditas pangan Kota Malang berasal dari kota/kabupaten sekitar), seperti Kabupaten Malang, Kabupaten Probolinggo, dan Kota Batu. Tingginya impor mengakibatkan ketergantungan penyediaan pangan dari kota/kabupaten sekitar, dampaknya pemerintah dan pedagang di pasar harus menyiapkan 
angaran yang tinggi untuk mendatangkan pangan.

Sebagian besar komoditas pangan yang tersedia di Kota Malang digunakan untuk bahan makanan atau konsumsi penduduk. Beberapa komoditas yang digunakan untuk bahan baku industri makanan antara lain, ubi kayu, kacang tanah, dan kelapa. Komoditas kelapa misalnya dalam industri makanan diolah menjadi santan yang akan digunakan penduduk dalam proses pengolahan makanan, pada akhirnya digunakan untuk konsumsi penduduk. Keadaan ini perlu dicermati apabila seluruh ketersediaan ini dikonsumsi oleh penduduk, maka akan timbul masalah gizi lebih (kegemukan) yang berdampak munculnya penyakit degeneratif.

Penggunaan bahan makanan selain untuk dikonsumsi penduduk adalah untuk pakan, bibit, industri non makanan, dan tercecer. Beberapa komoditas yang digunakan untuk pembuatan pakan adalah padi, beras, jagung, ubi jalar, ubi kayu, kedelai, kelapa, dan susu sapi. Komoditas pangan tersebut sebagian digunakan untuk pakan ternak, mengingat masih banyaknya peternakan sapi, ikan, dan unggas yang didominasi di Kecamatan Kedungkandang. Selain itu, penggunaan untuk bibit ditujukan untuk menjaga keberlangsungan komoditas pangan. Komoditas pangan yang digunakan untuk bibit antara lain kelompok sayur-sayuran, telur ayam buras, dan telur ayam itik, sedangkan untuk kelompok pangan lainnya yang diproduksi akan tetapi tidk ada sumbangan untuk bibit, diduga bibit berasal dari impor (luar Kota Malang). Penggunaan lainnya untuk industri non makanan hanya komoditas ubi kayu. Jumlah pangan yang tercecer menggambarkan jumlah pangan yang tidak dapat digunakan, disebabkan karena hilang, busuk, ataupun rusak selama proses distribusi.

\section{Pola Pangan Harapan Ketersediaan Pangan Kota Malang}

Tingkat ketersediaan pangan selain dilihat berdasarkan kecukupan gizinya, baik energi dan protein, juga dinilai dari segi keberagaman ketersediaan gizi berdasarkan Pola Pangan Harapan (PPH). PPH tingkat ketersediaan dihitung berdasarkan ketersediaan energi Neraca Bahan Makanan (NBM). Tingkat keberagaman ketersediaan pangan akan mendukung percapaian keberagaman konsumsi pangan sehingga dapat dicapai sasaran konsumsi pangan yang diharapkan. PPH digunakan sebagai acuan dalam mengetahui kualitas dan 
ketersediaan pangabn di Kota Malang yang digambarkan dari skor PPH dan komposisi kelompok pangan.

Skor PPH ketersediaan pangan untuk Kota Malang pada tahun 2016 sebesar 89,33. Skor PPH belum dikatakan ideal, dikarenakan belum mencapai skor ideal, yaitu 100 (BKP, 2014). Jika nilai skor PPH semakin mendekati angka ideal, maka dapat dikatakan ketersediaan pangan yang ada dalam suatu wilayah atau kota cukup beragam.

Tabel 2. Perhitungan PPH Ketersediaan Pangan Tahun 2016

\begin{tabular}{clcccccc}
\hline No & Kelompok Bahan Pangan & $\begin{array}{c}\text { Energi } \\
\text { (Kalori) }\end{array}$ & \% AKE & Bobot & Skor riil & $\begin{array}{c}\text { Skor } \\
\text { PPH }\end{array}$ & $\begin{array}{c}\text { Skor } \\
\text { Maks }\end{array}$ \\
\hline 1 & Padi-padian & 770 & 32,1 & 0,5 & 16,0 & 16,0 & 25,0 \\
2 & Umbi-umbian & 150 & 6,3 & 0,5 & 3,1 & 2,5 & 2,5 \\
3 & Pangan Hewani & 379 & 15,8 & 2,0 & 31,6 & 24,0 & 24,0 \\
4 & Minyak dan lemak & 402 & 16,7 & 0,5 & 8,4 & 5,0 & 5,0 \\
5 & Buah/biji berminyak & 35 & 1,5 & 0,5 & 0,7 & 0,7 & 1,0 \\
6 & Kacang-kacangan & 125 & 5,2 & 2,0 & 10,4 & 10,0 & 10,0 \\
7 & Gula & 230 & 9,6 & 0,5 & 4,8 & 2,5 & 2,5 \\
8 & Sayuran dan buah & 137 & 5,7 & 5,0 & 28,6 & 28,6 & 30,0 \\
9 & Lain-lain & - & - & - & - & - & - \\
\hline & Jumlah & 2.227 & 92,8 & & 103,6 & 89,93 & 100 \\
\hline
\end{tabular}

Sumber: PPH 2016, (Diolah)

Berdasarkan Tabel 2, ketersediaan pangan Kota Malang didominasi oleh kelompok pangan padi-padian, minyak dan lemak, serta pangan hewani. Merujuk pada perhitungan $\mathrm{PPH}$ terdapat 8 kelompok pangan yang dianalisis. Hasil perhitungan menunjukkan bahwa terdapat 3 kelompok pangan yang memiliki skor dibawah nilai skor maksimal $\mathrm{PPH}$, yaitu kelompok pangan padi-padian, kelompok pangan buah/biji berminyak, buah dan sayur. Kelompok pangan yang memiliki skor riil diatas skor diatas skor maksimal PPH terdapat 6 kelompok pangan, yaitu; umbi-umbian, pangan hewani, minyak dan lemak, kacang-kacangan, dan gula.
Formulasi Sasaran dan Kebutuhan Penyediaan serta Produksi Pangan Kota Malang

Berdasarkan data ketersediaan pangan melalui Neraca Bahan Makanan (NBM) Kota Malang Tahun 2016, dapat disusun formulasi sasaran Pola Pangan Harapan (PPH) dan kebutuhan penyediaan serta produksi pangan Kota Malang selama 3 tahun mendatang.

Tabel 3 menunjukkan bahwa ratarata ketersediaan energi menurut kelompok bahan pangan (kkal/kapita/hari) dari tahun 2016-2019 untuk memperoleh AKE ideal diperlukan peningkatan dan penurunan secara bertahap. 
Tabel 3. Sasaran PPH Kota Malang Berdasarkan Neraca Bahan Makanan Tahun 2016

\begin{tabular}{llcccc}
\hline \multirow{2}{*}{ No. } & \multirow{2}{*}{ Kelompok Bahan Pangan } & \multicolumn{5}{c}{ Rata-rata Ketersediaan Energi Menurut Kelompok Pangan } \\
& & \multicolumn{5}{c}{ Kkal/Kapita/Hari) } \\
\hline & Tahun & 2016 & 2017 & 2018 & 2019 \\
\hline 1. & Padi-padian & 770 & 913.13 & $1.056,56$ & 1,200 \\
2. & Umbi-umbian & 150 & 148.02 & 146.01 & 144 \\
3. & Pangan Hewani & 379 & 348.49 & 318,25 & 288 \\
4. & Minyak dan Lemak & 402 & 347.93 & 293,97 & 240 \\
5. & Buah/biji berminyak & 35 & 47.26 & 59,63 & 72 \\
6. & Kacang-kacangan & 125 & 123.12 & 121,56 & 120 \\
7. & Gula & 230 & 193.17 & 156,58 & 120 \\
8. & Sayuran dan Buah & 137 & 139.42 & 141,71 & 144 \\
9. & Lain-lain & - & 24.00 & 48,00 & 72 \\
\hline \multicolumn{7}{c}{ Jumlah } & 2.227 & 2.285 & 2.342 & 2.400 \\
\hline
\end{tabular}

Sumber: PPH 2016, (Diolah)

Formulasi sasaran dan kebutuhan penyediaan serta produksi di Kota Malang bila dilihat berdasarkan satuan ton, setiap kelompok pangan berbedabeda yaitu terdapat kelompok pangan yang perlu ditambah dan ada pula yang perlu dikurangi. Besarnya penambahan dan pengurangan penyediaan serta produksi setiap kelompok pangan tidak terlalu banyak. Secara lengkap formulasi sasaran dan kebutuhan penyediaan serta produksi disajikan pada Tabel 4.

Tabel 4. Formulasi Sasaran dan Kebutuhan Penyediaan serta Produksi di Kota Malang

\begin{tabular}{|c|c|c|c|c|c|}
\hline \multirow[t]{2}{*}{ No. } & \multirow[t]{2}{*}{ Kelompok Bahan Pangan } & \multicolumn{4}{|c|}{$\begin{array}{c}\text { Sasaran dan Kebutuhan Penyediaan dan Produksi menurut Kelompok } \\
\text { Pangan (ton) }\end{array}$} \\
\hline & & 2016 & 2017 & 2018 & 2019 \\
\hline 1. & Padi-padian & $1.068,03$ & $1.267,07$ & $1.466,10$ & $1.665,14$ \\
\hline 2. & Umbi-umbian & 208,17 & 205 & 202,60 & 199,82 \\
\hline 3. & Pangan Hewani & 524,54 & 483.57 & 441,60 & 399,63 \\
\hline 4. & Minyak dan Lemak & 557,68 & 482,80 & 407,91 & 333,03 \\
\hline 5. & Buah/biji berminyak & 48,41 & 65,57 & 82,74 & 99,91 \\
\hline 6. & Kacang-kacangan & 173,01 & 170,84 & 168,68 & 166,51 \\
\hline 7. & Gula & 318,81 & 268,04 & 217,28 & 166,51 \\
\hline 8. & Sayuran dan Buah & 190,28 & 193,46 & 196,64 & 199,82 \\
\hline 9. & Lain-lain & - & 33,30 & 66,61 & 99,91 \\
\hline & Jumlah & $3.089,93$ & $3.170,05$ & $3.250,16$ & $3.330,28$ \\
\hline
\end{tabular}

Sumber: PPH 2016, (Diolah)

\section{KESIMPULAN}

Berdasarkan penyusunan Neraca Bahan Makanan (NBM) dapat diketahui bahwa, total ketersediaan pangan energi sebesar $2.227 \mathrm{kkal} / \mathrm{kap} / \mathrm{hari}$, dan protein 63,77 gram/kap/hari. Hal ini menunjukkan, ketersediaan energi Kota
Malang belum memenuhi standar rekomendasi Angka Kecukupan Energi (AKE). Sedangkan ketersediaan protein Kota Malang sudah diatas ketersediaan minimal Angka Kecukupan Protein (AKP). AKE dan AKP yang direkomendasikan oleh Widyakarya 
Nasional Pangan dan Gizi (WNPG) X Tahun 2012, dimana AKE sebesar 2400 $\mathrm{kkal} / \mathrm{kap} / \mathrm{hari}$ dan protein sebesar 63 gram/kap/hari.

Nilai Pola Pangan Harapan (PPH) ketersediaan pangan sebesar 89,33 sedangkan nilai PPH idealnya adalah 100. Kondisi tersebut menunjukkan bahwa keragaman ketersediaan pangan di Kota Malang belum maksimal. Kelompok pangan yang memiliki skor kurang dari skor maksimal PPH adalah kelompok pangan padi-padian, buah biji berminyak, sayur dan buah, sedangkan kelompok bahan pangan lainnya meliputi; umbi-umbian, pangan hewani, minyak dan lemak, kacang-kacangan, dan gula melebihi skor maksimal PPH.

Angka Kecukupan Energi (AKE) dan Angka Kecukupan Protein (AKP) ideal dapat dicapai dengan peningkatan dan penurunan secara bertahap kelompok bahan pangan dari tahun 2016-2019. Kelompok bahan pangan yang memerlukan peningkatan ketersediaan meliputi, padi-padian, buah biji berminyak, sayuran dan buah. Sebaliknya kelompok bahan pangan umbi-umbian, minyak dan lemak, pangan hewani, kacang-kacangan, dan gula memerlukan penurunan.

\section{DAFTAR PUSTAKA}

Arifin B. (2012). Resiko dan Ketahanan Pangan di Daerah Sentra Padi Kabupaten.

Asmara, Fahriyah, dan Nugroho. (2016). Ketersediaan Energi, Protein, dan Lemak di Kabupaten Tuban : Pendekatan Neraca Bahan Makanan. Seminar Nasional Pembangunan Pertanian. Jurusan Sosial Ekonomi Pertanian, Fakultas Pertanian Universitas Brawijaya. Malang.

Pinrang. Dalam Gevisioner et all,. (2015). Kualitas Konsumsi Pangan di Daerah Defisit Pangan Provinsi Riau. Jurnal Gizi Pangan 10 (3); 233-240.

Badan Ketahanan Pangan (BKP). (2015). Kajian Instrumen Kerawanan Pangan. Jakarta: BKP Kementrian Pertanian.

- (2015). Rencana Strategis Badan Ketahanan Pangan Tahun 20152019. Kementerian Pertanian. 